Research Article

\title{
The Antidepressant like action of ethanolic extract of areca catechu on behavioral models of depression in rats
}

\author{
Manohar M. Bende ${ }^{1}$, Sujata Dudhgaonkar ${ }^{2}$, Raviraj S. Jagdhani ${ }^{2}$, Naren P. Bachewar ${ }^{2}$
}

${ }^{1}$ Department of Pharmacology, GMC Chandrapur, Maharashtra, India

${ }^{2}$ Department of Pharmacology, SVNGMC Yavatmal,

Maharashtra, India

Received: 13 July 2016

Accepted: 09 August 2016

*Correspondence to:

Dr. Raviraj S. Jagdhani,

Email: rsjagdhani@gmail.com

Copyright: (C) the author(s), publisher and licensee Medip Academy. This is an openaccess article distributed under the terms of the Creative Commons Attribution NonCommercial License, which permits unrestricted noncommercial use, distribution, and reproduction in any medium, provided the original work is properly cited.

\begin{abstract}
Background: The objective was to investigate the anti-depressant like activity of areca catechu nut ethanolic extract (ACEE) using behavioural tests in rats.

Methods: Forced swim test (FST) and tail suspension test (TST) were used to assess the anti-depressant like effect of ACEE rats. Motor coordination was also assessing using rota-rod test in rats to see generalised CNS depression. Fluoxetine was the reference standard drug. Rats were divided into four groups with six rats in each group namely control group, fluoxetine $10 \mathrm{mg} / \mathrm{kg}$ group, ACEE $50 \mathrm{mg} / \mathrm{kg}$ group and fluoxetine $5 \mathrm{mg} / \mathrm{kg}$ plus ACEE $25 \mathrm{mg} / \mathrm{kg}$. All treatments were administered orally.

Results: The areca nut ethanolic extract (ACEE) $(50 \mathrm{mg} / \mathrm{kg}$ oral) exhibited antidepressant like activity i.e. decrease the duration of immobility time (sec) in acute forced swim test (FST) and in acute tail suspension test (TST) in rats $(104 \pm 1.7,95 \%$ CI 99.65 to $108.4, p<0.01)$ Vs control and $(136.3 \pm 1.94,95 \%$ CI 131.3 to $141.3, \mathrm{p}<0.01)$ Vs control respectively. ACEE in low dose of $25 \mathrm{mg}$ potentiated the anti-depressant activity of low dose fluoxetine $5 \mathrm{mg} / \mathrm{kg}$ in both the test $102.3 \pm 2.60$, CI 95.64 to $109.0 \mathrm{p}<0.01)$ Vs control. The ACEE did not produce motor incoordination in rats.

Conclusions: The results of present study suggest that the areca catechu nut ethanolic extract $50 \mathrm{mg} / \mathrm{kg}$ possess potential anti-depression like effect without generalized CNS depression. Further studies are needed to confirm this.
\end{abstract}

Keywords: Areca catechu ethanolic extract, Fluoxetine, Forced swim test, Tail suspension test, Anti-depression activity, Immobility time (sec)

\section{INTRODUCTION}

The Major depression is a serious chronic mental illness with pessimism and low self-esteem. There occur functional deficiency of monoamine neurotransmission viz. noradrenaline, 5-HT, and dopamine. The known antidepressants (TCA/MAO-I, SSRI, SNRI) facilitate monoamine neurotransmission (monoamine theory). ${ }^{1}$ Other causes underlying major depression are under investigations. Anti-depressant drugs show side effect and effectiveness is limited, $30 \%$ may not respond. Hence the search for new anti-depressant without side effect is important. ${ }^{9}$ Currently there is increasing research on traditional AYUSH system of medicine., ${ }^{71}$ Traditional medicines on the basis of their known efficacy observations traditionally are considered safe and free from adverse effect and toxicity unlike allopathic medicines. Efforts are underway to develop natural herbs for their anti-depressant use. ${ }^{8}$ India has reach herbs used traditionally for various ailments. Few have been explored by various researchers for anti-depressant activity. Areca catechu has been anecdotally reported for anti-depressant action. ${ }^{9}$ Hence the aim of present study was to investigate anti-depressant activity of areca catechu nut in experimental rats.

\section{METHODS}

The experimental protocol was approved by IAEC (registration no.805/03/ca/CPCSEA).

Areca catechu nuts were collected locally and authenticated by local botanist.

a) Preparation of ethanolic extract: areca nuts (betel nuts) were crushed into fine powder. The powder was subjected to hot percolation using ethanol (1:4). The extract then passed through filter paper 1. Ethanol was evaporated by heating, drying was done in desiccator. 
b) Rats and housing: Male Sprague Dawley rats (150$250 \mathrm{gm}$ ) were obtained from rats house facility of savangi meghe, Maharashtra. They were kept at $(25$ $\pm 1^{\circ} \mathrm{C}$ ), 12 hour light / dark cycle. Food and water were provided ad libitum. All experiments were performed as per CPCSEA guidelines between 9am to $5 \mathrm{pm}$. All treatments drugs or chemical or vehicle were administered orally in rat. Control was tween 80.

- Total 24 rats were divided into 4 groups. In each group there were 6 rats.

c) Chemicals/drugs: Chemicals/drug was purchased from local market.

- Fluoxetine - Sun Pharma

- Dosing - doses for anti-depressant activity were selected from previous studies. Fluoxetine (10 $\mathrm{mg} / \mathrm{kg}$ ), Areca catechu ethanolic extract (ACEE) (50 $\mathrm{mg} / \mathrm{kg})^{1}$

d) Methods:

- Rota-rod test: The effect on motor co-ordination was assessed using rota-rod individually in rats ${ }^{[17]}$. Rats were trained to remain on rota-rod for 3 minutes at speed $25 \mathrm{rpm}$. On the day of experiment either vehicle or test drug was administered orally, the ability of rats to remain on rota-rod was assessed 30 min after. Fall time was noted.

- Forced swim test (FST): (Porsolt et al 11977). ${ }^{3}$ The Experiment was conducted as per the method previously described by porsolt et $\mathrm{al}^{3}$ Rats were placed in glass tank $(15 \times 15 \times 50 \mathrm{~cm})$ filled with water (at $23-25^{\circ} \mathrm{C}$ ) up to a level of $15 \mathrm{~cm}$. Treatment was given 1 hour prior to test session of $.6 \mathrm{~min}$. Total duration of immobility time (in seconds) in $6 \mathrm{~min}$ was counted. In each rats immobility time (sec) i.e. rats remain static or making passive movements to keep its head above water level for $4 \mathrm{~min}$ were recorded after initial $2 \mathrm{~min}$.

- Tail suspension test (TST): (Steru L et al.). ${ }^{4}$ The test was performed according to method described by Steru L et al. Each rat was suspended by adhesive tape to a flat surface placed approximately $1 \mathrm{~cm}$ from tail tip and $50 \mathrm{~cm}$ below surface. Immobility time in seconds was measured for $6 \mathrm{~min}$. Immobility was considered when the rats hung passively motionless without limb movement.

e) Statistical analysis: The values were expressed as mean \pm SEM. The difference between various mean were tested by one way ANOVA followed by Dunnet multiple comparison test. $\mathrm{P}$ value $<0.05$ was considered statistically significant. Analysis was done by using graph pad prism version 5 .

\section{RESULTS}

The rats treated with control/fluoxetine/ACEE/ fluoxetine + ACEE remained on rota-rod for $3 \mathrm{~min}$. The above treatments did not induced motor in-coordination versus control ( $\mathrm{p}>0.05)$. Results are summarised in Figure 1.

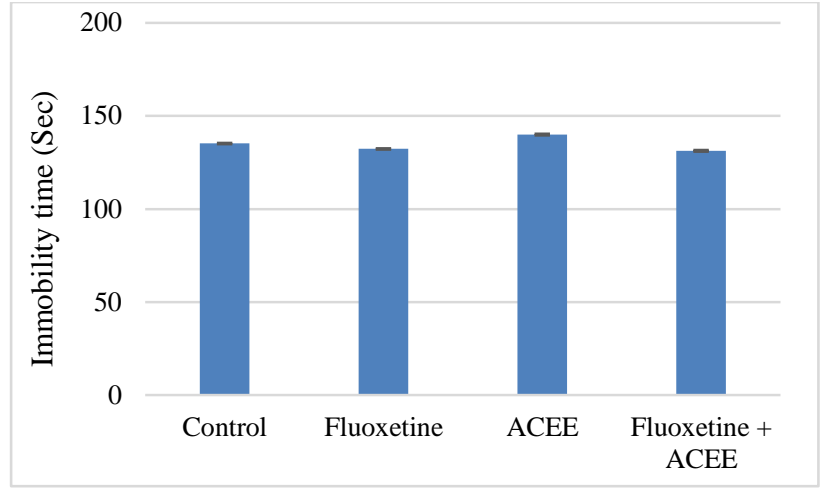

Figure 1: Effect of various treatments on rota-rod test in rats.

Results are summarised in Table1 and Figure 2.

Table 1: Forced swim test (FST).

\begin{tabular}{|lllll|}
\hline Groups & $\begin{array}{l}\text { Dose } \\
(\mathbf{m g} / \mathrm{kg})\end{array}$ & $\begin{array}{l}\text { Immobility } \\
\text { time (s) } \\
(\mathbf{M} \pm \text { SEM) }\end{array}$ & $\begin{array}{l}\mathbf{9 5 \%} \\
\mathrm{CI}\end{array}$ & $\begin{array}{l}\mathbf{p} \\
\text { value }\end{array}$ \\
$\begin{array}{l}\text { Control / } \\
\text { Tween } 80\end{array}$ & $1 \mathrm{ml}$ & $144.7 \pm 17.35$ & $\begin{array}{l}100.1 \text { to } \\
189.3\end{array}$ & \\
\hline Fluoxetine & 10 & $81.83 \pm 1.7$ & $\begin{array}{l}77.36 \text { to } \\
86.31\end{array}$ & $* * *$ \\
\hline ACEE & 50 & $104 \pm 1.7$ & $\begin{array}{l}99.65 \text { to } \\
108.4\end{array}$ & $* *$ \\
\hline $\begin{array}{l}\text { Fluoxetine } \\
+ \text { ACEE }\end{array}$ & $5+25$ & $102.3 \pm 2.6$ & $\begin{array}{l}95.64 \text { to } \\
109\end{array}$ & $* *$ \\
\hline
\end{tabular}

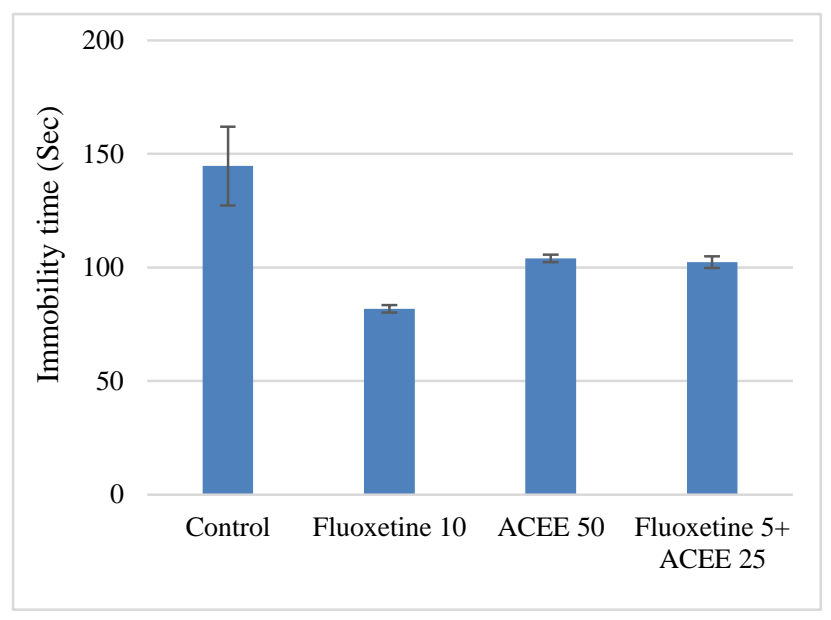

Figure 2: Effect of various treatments on Forced swim test (FST) in rats.

Effect of fluoxetine and ethanolic extract of areca catechu (oral) on immobility time (sec) in FST in rats $<30 \mathrm{~min}$ Vs tween 80 . Data are $M \pm$ SEM. Statistical analysis- one way ANOVA followed by post hoc dunnet test. **p $<0.01, * * * \mathrm{P}<0.001$ vs control; $\mathrm{n}=6$.

Results are summarised in Table 2 and Figure 3. 
Table 2: Tail suspension test (TST).

\begin{tabular}{|lllll|} 
Groups & $\begin{array}{l}\text { Dose } \\
\text { (mg/kg) }\end{array}$ & $\begin{array}{l}\text { Immobility } \\
\text { time (s) } \\
(\mathbf{M} \pm \text { SEM) }\end{array}$ & $95 \%$ CI & $\begin{array}{l}\text { p } \\
\text { value }\end{array}$ \\
\hline $\begin{array}{l}\text { Control / } \\
\text { Tween } 80\end{array}$ & $1 \mathrm{ml}$ & $142.8 \pm 2.55$ & $\begin{array}{l}136.3 \text { to } \\
149.4\end{array}$ & \\
\hline Fluoxetine & 10 & $118.3 \pm 4.716$ & $\begin{array}{l}106.2 \text { to } \\
130.5\end{array}$ & $* * *$ \\
\hline ACEE & 50 & $136.3 \pm 1.94$ & $\begin{array}{l}131.3 \text { to } \\
141.3\end{array}$ & $* *$ \\
\hline $\begin{array}{l}\text { Fluoxetine } \\
+ \text { ACEE }\end{array}$ & $5+25$ & $102.3 \pm 2.60$ & $\begin{array}{l}95.64 \text { to } \\
109\end{array}$ & $* *$ \\
\hline
\end{tabular}

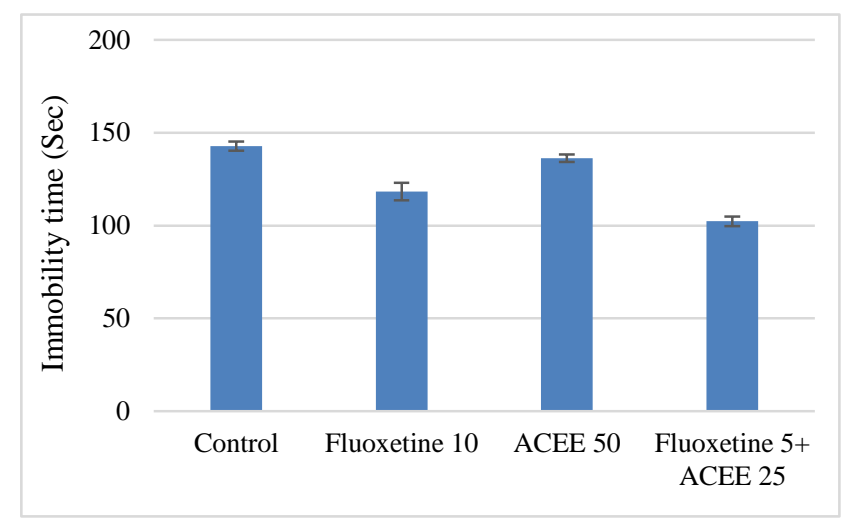

Figure 3: Effect of various treatments on tail suspension test (TST) in rats.

Effect of fluoxetine and ethanolic extract of areca catechu on immobility time ( $\mathrm{sec}$ ) in TST in rats $<30 \mathrm{~min}$ Vs tween 80. Data are $M \pm$ SEM. Statistical analysis -one way ANOVA followed by post hoc dunnet test. ** $\mathrm{P}<0.01$, $* * * \mathrm{P}<0.001$ versus control. $\mathrm{n}=6$.

\section{FST}

The reference compound, anti-depressant fluoxetine (10 $\mathrm{mg} / \mathrm{kg}$ ) statistically significantly reduced immobility time (s) $(81.83 \pm 1.7$, CI 77.36 to $86.31, \mathrm{p}<0.001)$ compared to control in rats. The efficacy was $22.73 \%$.

ACEE at dose $(50 \mathrm{mg} / \mathrm{kg})$ in rats statistically significantly reduced immobility time (s) $(104 \pm 1.7$, CI 99.65 to 103.4 , $\mathrm{p}<0.01)$ compared to control. The action was less than fluoxetine $10 \mathrm{mg} / \mathrm{kg}$. The efficacy was $28.88 \%$.

Combination of low dose fluoxetine $5 \mathrm{mg} / \mathrm{kg}$ and low dose ACEE $25 \mathrm{mg} / \mathrm{kg}$ statistically significantly reduced immobility time (s) $(102.3 \pm 2.6$, CI 95.64 to $109, \mathrm{p}<0.01)$ compared to control in rats. The efficacy was $28.41 \%$.

Low dose ACEE potentiated the action of low dose of fluoxetine implying that ACEE has anti-depressant like action which is less than fluoxetine.

\section{TST}

The reference compound, anti-depressant fluoxetine (10 $\mathrm{mg} / \mathrm{kg}$ ) statistically significantly reduced immobility time (s) $(118.3 \pm 4.716$, CI 106.2 to $130.5, \mathrm{p}<0.001)$ compared to control in rats in TST test. The efficacy was $32.86 \%$.

The ACEE at dose $(50 \mathrm{mg} / \mathrm{kg})$ in rats statistically significantly reduced immobility time (s) $(136.3 \pm 1.94, \mathrm{CI}$ 131.3 to $141.3, \mathrm{p}<0.01)$ compared to control. The action was less than fluoxetine $10 \mathrm{mg} / \mathrm{kg}$. The efficacy was $37.86 \%$.

The Combination of low dose fluoxetine $5 \mathrm{mg} / \mathrm{kg}$ and low dose ACEE $25 \mathrm{mg} / \mathrm{kg}$ statistically significantly reduced immobility time (s) $(102.3 \pm 2.6$, CI 95.64 to 109 , $\mathrm{p}<0.01)$ compared to control in rats. The efficacy was 28.33\%. Low dose ACEE potentiated the action of low dose of fluoxetine, showing that ACEE has antidepressant like action which is lower than fluoxetine.

\section{DISCUSSION}

The Results of present study proved that ACEE has antidepression like action as it significantly reduced immobility time in animal models, which was lower to fluoxetine (FST) without motor incoordination proving that it is not a generalised CNS depressant. Two classical rat models (FST and TST) were used to evaluate antidepressant like effect of ethanolic extract of areca catechu nut.

Efficacy of fluoxetine $10 \mathrm{mg} / \mathrm{kg}$ (a standard antidepressant) on immobility time (sec) in FST was significant $(81.83 \pm 1.7,95 \%$ CI 77.36 to 86.31 , p < 0.001$)$ Vs control. The immobility time ( $\mathrm{sec}$ ) was lower than that of fluoxetine.

The FST was commonly used and validated test to assess anti-depressant like effect of AECC in previous studies ${ }^{[9]}$. In the present study also areca nut ethanolic extract (ACEE) $(50 \mathrm{mg})$ induced significant decline in immobility time $(\mathrm{sec})$ in rats $(104 \pm 1.7,95 \%$ CI 99.65 to $108.4, \mathrm{p}$ $<0.01)$ Vs control, exhibiting potential anti-depressant action (Figure 2). This is in agreement with earlier reports but they got improved results on these tests using aqueous extract of areca catechu. ${ }^{16}$ At dose of $50 \mathrm{mg}$ of ACEE however there was significant difference in reducing immobility time (sec) between fluoxetine and ACEE, indicating that the efficacy of fluoxetine was more than ACEE. The combination of fluoxetine and ACEE in low dose of $5 \mathrm{mg}$ and $25 \mathrm{mg}$ respectively potentiated the activity (immobility time (sec) $102.3 \pm 2.60,95 \%$ CI 95.64 to $109.0, \mathrm{p}<0.01)$ Vs control suggesting that fluoxetine and ACEE may be working by different mechanisms.

Similar results were noted on TST. Fluoxetine $10 \mathrm{mg} / \mathrm{kg}$ showed highly significant reduction in immobility time Vs control $(142.8 \pm 2.55,95 \%$ CI 136.3 to $149.4 \mathrm{p}<0.001)$. 
ACEE also showed significant reduction (136.3 \pm 1.94 , 95\%CI 131.3 to 141.3 , p <0.01) Vs control but lower than Fluoxetine $10 \mathrm{mg} / \mathrm{kg}$. Low dose of fluoxetine and ACEE potentiated the activity significantly $(102.3 \pm 2.60,95.64$ to $109.0 \mathrm{p}<0.01) \mathrm{Vs}$ control.

The alkaloid of arecholine has been considered as active principle underlying most of the biological actions of areca catechu nut. Arecholine is choline esterase inhibitor with established efficacy in Alzheimer dementias, the hallmark of Alzheimer's disease is reduced cognitive behaviour. $^{2}$ Arecholine slows down improper memory. Areca catechu nut is definitely not a CNS stimulant. ${ }^{15}$ Arecholine act on multiple muscarinic receptors $\left(\mathrm{M}_{1}, \mathrm{M}_{2}\right.$, $\mathrm{M}_{3}$, and M4). Arecholine improves memory in healthy volunteer. ${ }^{4}$ Arecholine slows down improper memory (dementia) but is carcinogenic ${ }^{[13,14]}$. Other alkaloids contained in areca nuts are pyridine, piperidine, guvacine, and guvacholine, the later showed antidepressant activity in experiments. ${ }^{5,8}$ Areca catechu nut is definitely not a CNS stimulant. ${ }^{15}$ Exactly which alkaloid is antidepressant and whether acetylcholine got any role underlying depression is unknown.

Pathophysiology of major depression is complex, not fully understood. ${ }^{2}$ Many neurotransmitters are involved in depression. ${ }^{26}$ Monoamine theory of depression says that monoamines are low in brains of major depression. ${ }^{2}$ Fluoxetine increases serotonin levels in brain by selective serotonin reuptake inhibition. ${ }^{10}$ Areca nut ethanolic extract may have similar effect on monoamine. ${ }^{6}$ Dang 2009 reported natural saponin has anti-depressant action by increase NA, increase $5-\mathrm{HT}), \mathrm{MAOI}^{7}{ }^{7}$ In the study by Ghulam Abbas et al using hippocampal slices, areca nut caused significant elevation of serotonin and noradrenaline proving this mechanism behind its antidepressant like action.

However further more elaborate investigations are required to confirm the exact mechanism of action ACEE.

\section{CONCLUSION}

Our study confirmed that areca catechu ethanolic extract has anti-depressant like effect as it statistically significantly reduced immobility time (sec) in forced swim test (FST) and in tail suspension test (TST) without impairment in motor coordination in rats can be attributed to enhanced serotonin and noradrenalin levels in brain. Though further studies needed.

\section{Limitations}

Anti-depressant effect was seen after acute tests. Conventional anti-depressant take 2-3 weeks to act, hence effect after chronic treatment is needed to be studied using chronic models of depression. Levels of different alkaloids contained in areca catechu nut are needed to be estimated to study their anti-depressant effect.
Funding: No funding sources Conflict of interest: None declared

Ethical approval: The study was approved by the Institutional Ethics Committee

\section{REFERENCES}

1. Ahsana D, Shagufta K. Behavioral and Biochemical Studies of can be attributed toenhancement of serotonin and Dichloromethane Fraction from the Areca catechu nut. Pharmacology Biochemistry and Behavior. 2000;65(1):1-6.

2. Pytka K, Podkowa K, Rapacz A, Podkowa A, Zmudzka E, Olczyk A. The role of serotonergic, adrenergic and dopaminergic receptors in antidepressant like effect. Pharmacol Rep. 2016;68:263-74.

3. Porsolt RD, Bertin A, Jalfre M. Behavioral despair in mice: a primary screening test for antidepressants. Archives Internationals de pharmacodynamics ET Thetapie, 1977;229(2):32736.

4. Steru L, Chermat R, Thierry B, Simon P. The tail suspension test: A primary screening test for antidepressants in mice. Psychopharmacology (Berl). 1985;85:367-70.

5. Pytka K, Dziubina A, Mlyniec K, Dziedziczak A, Zmudzka E, Furgala A. The role of glutaminergic, GABA-ergic, and cholinergic receptors in depression and antidepressant like effect. Pharmacol Rep. 2016;68:443-50.

6. Dang H, Chen Y, Liu X. Antidepressant effect of ginseng total saponin in forced swim test And chronic mild stress model of depression. Prog Neuro-Psychopharmacol Biol Psychiatry. 2009;33:1417-24.

7. Ara I, Bano S. St. John's Wort modulates brain regional serotonin metabolism in swim stressed rats. Pak J Pharm Sci. 2009;22:94-101.

8. Gautam RK, Dixit PK, Mittal S. Herbal Sources of Antidepressant Potential: A Review. Int. J. Pharm. Sci. Rev. Res. 2013;18(1):86-91.

9. Cryan JF, Markou A, Lucki I. Assessing antidepressant activity in rodents: recent developments and future needs. Trends Pharmacol Sci. 2002;23(5):238-45.

10. Abbas G, Naqvi S, Erum S, Ahmed S, Atta-urRahman, Dar A. Potential antidepressant activity of Areca catechu nut via elevation of serotonin and noradrenaline in the hippocampus of rats. Phytother Res. 2013;27(1):39-45.

11. Sarris J, Panossian A, Schweitzer I, Stough C. Andrew Scholey Herbal Medicine in Depression, Anxiety and Insomnia: A Review of Psychopharmacology and Clinical Evidence. European neuropsychopharmacology: the journal of the European College of Neuropsychopharmacology. 2011;21(12):841-60.

12. Pytka K, Zmudzka E, Lustyk K, Rapacz A, Olczyk A, Galuszka A, et al. The antidepressant- and 
anxiolytic-like activities of new xanthone derivative with piperazine moiety in behavioral tests in mice. Indian Journal of Pharmacology. 2016;48(3):28691.

13. Lin KH, Lin CY, Liu CC, Chou MY, Lin JK. Arecoline N-oxide: its mutagenicity and possible role as ultimate carcinogen in areca oral carcinogenesis. J Agric Food Chem. 2011;59(7):3420-8.

14. Sharan RN, Mehrotra R, Choudhury Y, Asotra K. Association of Betel Nut with Carcinogenesis: Revisit with a Clinical Perspective. PLoS One. 2012;7(8):e42759.
15. Gupta PC, Ray CS. Epidemiology of betel quid usage. Ann Acad Med Singapore. 2004;33(4):31-6.

16. Dar A, Khatoon S, Rahman G, Atta-Ur-Rahman. Anti-depressant activities of Areca catechu fruit extract. Phytomedicine. 1997;4(1):41-5.

17. Kulkarni SK. Hand Book of Experimental Pharmacology, 3rd edition. pp. 131-139.

Cite this article as: Bende MM, Dudhgaonkar S, Jagdhani RS, Bachewar NP. The Antidepressant like action of ethanolic extract of areca catechu on behavioral models of depression in rats. Int $\mathrm{J}$ Basic Clin Pharmacol 2016;5:2098-2102. 